\title{
A Structural Analysis on the Creativity, Self-Leadership, Self- Determination, Career Decision-Making Self-Efficacy, and Career Preparation Behavior of College Students who participated in the Training Courses from Lifelong Educators
}

\author{
Myeung-sin Park, Sang-hoon Han \\ Department of Education, Chungnam National University \\ 99 Daehak-ro, Yuseong-gu, Daejeon, Korea \\ parkms0335@cnu.ac.kr; hoona@cnu.ac.kr
}

\begin{abstract}
We conducted a structural analysis on the creativity, self-leadership, self-determination, career decision-making self-efficacy, and career preparation behavior of college students who participated in the training courses of lifelong educators. The results are as follows: First, the creativity has meaningful influence on career preparation behavior. Second, the creativity has meaningful influence on selfleadership, self-determination, and career decision-making self-efficacy. Third, their self-leadership and self-determination, and career decision-making self-efficacy has meaningful influence on career preparation behavior. Fourth, we confirmed that self-leadership, self-determination, and career decision-making self-efficacy have meaningful mediation influence between the creativity, and career preparation behavior.
\end{abstract}

Keywords: College students, Creativity and Self-leadership, Self-determination, Career decision-making self-efficacy, and Career preparation behavior

\section{Introduction}

In modern society, college students, who struggle to find their place in society, are required to make great efforts to develop various skills such as creativity, self-leadership, self-determination, career decision-making self-efficacy, and career preparation behavior. In order to help them develop such skills, many countries and universities are recently providing various training programs, as well as operating job centers, supporting work experience, implementing work \& study systems, and promoting LINC projects. These support programs need to be continued to lower the high youth unemployment rate and help college students find jobs in societ.

Career preparation behavior leads college students to engage in actual and concrete behavior to achieve their goals, for which it is being considered as a very important factor in career decision-making [1-5]. It is, therefore, very significant for this study to analyze the creativity, self-leadership, selfdetermination, career decision-making self-efficacy, and career preparation behavior of college students who are preparing to find jobs.

Therefore, it is meaningful to investigate the structural analysis between their creativity, and selfleadership, self-determination, career decision-making self-efficacy, and career preparation behavior. In order to provide theoretical and empirical data to promote career preparation behavior in college students based on the results of the analysis, the following research questions were assigned: 
Myeung-sin Park, Sang-hoon Han; A Structural Analysis on the Creativity, Self-Leadership, Self-Determination, Career Decision-Making Self-Efficacy, and Career Preparation Behavior of College Students who participated in the Training Courses from Lifelong Educators, Advances in Image and Video Processing, Volume 5 No 4, Aug (2017); pp: 11-16

First, how does college students' creativity influence their career preparation behavior? Second, how does college students' creativity influence their, self-leadership, self-determination, and career decision-making self-efficacy? Third, how does college students', self-leadership, self-determination, career decision-making self-efficacy influence career preparation behavior? Fourth, how does college students' creativity influence career preparation behavior with mediation of, self-leadership, selfdetermination, and career decision-making self-efficacy?

\section{Research Methods and Procedures}

\subsection{Research Objects}

Table 1. Demographic characteristics $(n=392)$

\begin{tabular}{|c|c|c|c|c|c|c|c|}
\hline variables & contents & $\begin{array}{c}\text { frequency } \\
\text { (n) }\end{array}$ & $\begin{array}{c}\text { proportion } \\
(\%)\end{array}$ & variables & contents & $\begin{array}{c}\text { frequency } \\
\text { (n) }\end{array}$ & $\begin{array}{c}\text { proportion } \\
(\%)\end{array}$ \\
\hline \multirow{2}{*}{ sexuality } & man & 185 & 47.2 & \multirow{5}{*}{$\begin{array}{l}\text { Participa } \\
\text { tion } \\
\text { period }\end{array}$} & $\begin{array}{c}1-2 \\
\text { semesters }\end{array}$ & 40 & 10.2 \\
\hline & woman & 207 & 52.8 & & $\begin{array}{c}3-4 \\
\text { semesters }\end{array}$ & 76 & 19.4 \\
\hline \multirow{4}{*}{ years } & $\begin{array}{r}20-21 \\
\text { years }(a)\end{array}$ & 87 & 22.2 & & $\begin{array}{c}\text { 5-6 } \\
\text { semesters }\end{array}$ & 182 & 46.4 \\
\hline & $\begin{array}{r}22-23 \\
\text { years }(b)\end{array}$ & 179 & 45.7 & & $\begin{array}{c}7-8 \\
\text { semesters }\end{array}$ & 94 & 24.0 \\
\hline & $\begin{array}{r}24-25 \\
\text { years }(c)\end{array}$ & 96 & 24.5 & & $\begin{array}{c}9-10 \\
\text { semesters }\end{array}$ & 39 & 9.95 \\
\hline & $\begin{array}{l}25 \text { years } \\
\text { over }(d)\end{array}$ & 30 & 7.7 & \multirow{5}{*}{$\begin{array}{c}\text { courses } \\
\text { number } \\
\text { completed }\end{array}$} & $\begin{array}{c}1-2 \\
\text { courses }\end{array}$ & 62 & 15.9 \\
\hline \multirow{4}{*}{$\begin{array}{c}\text { academic } \\
\text { years }\end{array}$} & year 1 & 12 & 3.1 & & $\begin{array}{c}\text { 3-4 } \\
\text { courses }\end{array}$ & 64 & 16.3 \\
\hline & year 2 & 79 & 20.2 & & $\begin{array}{c}\text { 5-6 } \\
\text { courses }\end{array}$ & 79 & 20.2 \\
\hline & year 3 & 116 & 29.6 & & $\begin{array}{c}7-8 \\
\text { courses }\end{array}$ & 64 & 16.3 \\
\hline & year 4 & 185 & 47.2 & & $\begin{array}{c}9-10 \\
\text { courses }\end{array}$ & 41 & 10.5 \\
\hline
\end{tabular}

\subsection{Measurement Instruments}

As a measuring tool of creativity, a tool developed by Eun Lee Jeong and Yong han Park[3], which consists of total 36 questionnaires, including 8 on creative flexibility and 5 on and alternative solving and 6 on altruistic self-confidence and 6 on relational openness and 3 on distinctive independence and 3 on exploratory immersive. As a measuring tool of self-leadership the RSLQ(Revised Self-Leadership Questionnaire) was measured with the measurement scale developed by Houghton \& Neck[4], which consists of total 35 questionnaires, including 18 on action-oriented strategy and 5 on natural reward strategy and 12 on constructive thinking strategy. As a measuring tool of self-determination, a tool used by Jinsuk Ryu [2] and Myeongshin Park [9-10], which consists of total 15 questionnaires, including 6 on autonomy and 3 on efficacy and 6 on relationship. As a measuring tool of career decision-making selfefficacy, a tool translated by Gihak Lee and Hakju Lee [17] for domestic college students from a scale developed by Betz \& Klein \& Taylor [6], which consists of total 25 questionnaires, including 5 on each of the following: self-assessment: information collection, setting goals, career plan, and problem 
solving. As a measuring tool of career preparation behavior, a career preparation behavior measuring tool was used which was revised by Taeyong Ko [7] from a measuring tool developed by Bonghwan Kim [6], which consists of total 17 questionnaires, including 12 on activities of exploration and 5 on activities of preparation.

\subsection{Data Collection and Analysis}

SPSS 22.0 Program was used for the calculations of Cronbach's reliability coefficient and correlation analysis, descriptive statistics analysis and frequency analysis to analyze collected data. Then, the confirmatory factor analysis was conducted using the AMOS 22.0 Program. To validate the structural equation modeling, the effect on measurement model was identified.

\section{Research Results}

\subsection{Empirical Tests on Structural Relations of the Measurement Model}

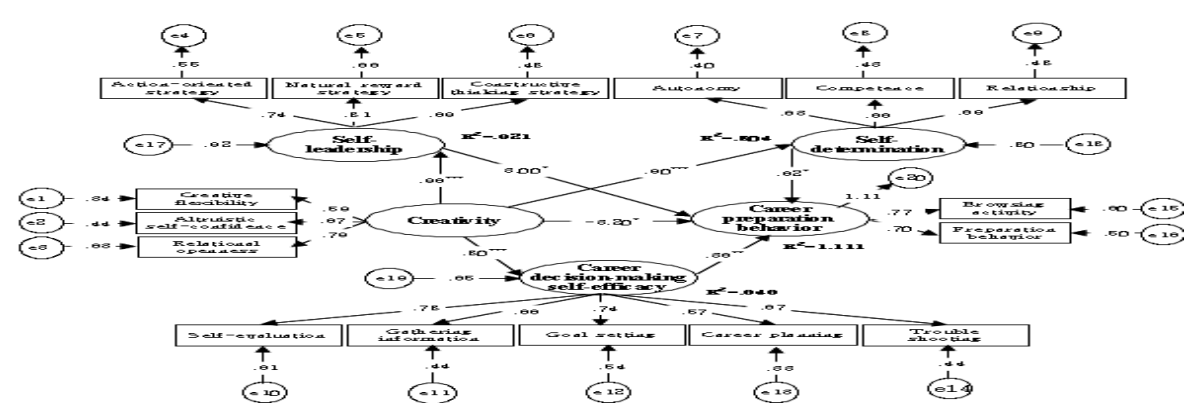

${ }^{*} p<.05^{* *} p<.01{ }^{* * *} p<.001$, Path Coefficient: Regression Coefficients $(B)$

Figure. 2. Structural relations model the path of the measurement model

Table 2. Fit indices for the measurement model

\begin{tabular}{c|c|c|c|c|c|c|c|c|c|c}
\hline Division & $\mathrm{X}^{2}$ & $\mathrm{p}$ & $\mathrm{df}$ & CFI & GFI & AGFI & IFI & TLI & RMR & RMSEA \\
\hline Fit indices & 560.309 & .000 & 97 & .943 & .938 & .973 & .944 & .905 & .039 & .071 \\
\hline $\begin{array}{c}\text { Optimal } \\
\text { cutoff }\end{array}$ & - & $<.05$ & - & \multicolumn{7}{|c}{$>$} \\
\hline
\end{tabular}

2.2 Decomposition of the Influence on the Structural Path of the Measurement Model

Table 3. Path coefficients and explanatory power of the measurement model (SMC/R)

\begin{tabular}{lllllll}
\hline hypothesis path & B & B & \multicolumn{1}{c}{ S.E. } & C.R. & & \\
creativity & $\rightarrow$ & $\begin{array}{l}\text { career } \\
\text { preparation } \\
\text { behavior }\end{array}$ & -3.465 & -3.202 & 1.518 & $-2.283^{*}$ \\
creativity & $->$ & self-leadership & .915 & .960 & .063 & $14.527^{* * *}$ \\
\hline creativity & $->$ & $\begin{array}{l}\text { self- } \\
\text { determination }\end{array}$ & .679 & .896 & .059 & $11.454^{* * *}$ \\
\hline creativity & $->$ & $\begin{array}{l}\text { career } \\
\text { decision- } \\
\text { making } \\
\text { self-efficacy }\end{array}$ & .695 & .803 & .061 & $11.413^{* * *}$ \\
\hline self-leadership & $\rightarrow$ & $\begin{array}{l}\text { career } \\
\text { preparation } \\
\text { behavior }\end{array}$ & .3 .405 & 3.000 & 1.519 & $2.241^{*}$ \\
\hline
\end{tabular}


Myeung-sin Park, Sang-hoon Han; A Structural Analysis on the Creativity, Self-Leadership, Self-Determination, Career Decision-Making Self-Efficacy, and Career Preparation Behavior of College Students who participated in the Training Courses from Lifelong Educators, Advances in I mage and Video Processing, Volume 5 No 4, Aug (2017); pp: 11-16

\begin{tabular}{|c|c|c|c|c|c|}
\hline self-determination & $\begin{array}{l}\text { career } \\
\text { preparation } \\
\text { behavior }\end{array}$ & .886 & .621 & .408 & $2.172^{*}$ \\
\hline $\begin{array}{l}\text { career decision-making } \\
\text { self-efficacy }\end{array}$ & $\begin{array}{l}\text { career } \\
\text { preparation } \\
\text { behavior }\end{array}$ & .455 & .364 & .160 & $2.835^{* *}$ \\
\hline \multicolumn{6}{|c|}{ self-leadership SMC/R² .921(92.1\%), self-determination SMC/R2 .804(80.4\%) } \\
\hline \multicolumn{6}{|c|}{$\begin{array}{l}\text { career decision-making self-efficacy } S M C / R^{2} .646(64.6 \%) \\
\text { career preparation behavior } S M C / R^{2} 1.111(111.1 \%)\end{array}$} \\
\hline${ }^{*} p<.05^{* *} p<.01^{* * *} p<.001$ & & & & & \\
\hline
\end{tabular}

\subsection{Decomposition effect on the Structural Model of the Measurement Path}

Table 4. Degradation effect of the measurement model

\begin{tabular}{|c|c|c|c|c|c|}
\hline \multirow{2}{*}{\multicolumn{2}{|c|}{ variables }} & \multicolumn{4}{|c|}{ life core ability } \\
\hline & & \multirow{2}{*}{$\begin{array}{c}\begin{array}{c}\text { direct } \\
\text { effects }\end{array} \\
.960\end{array}$} & \multirow{2}{*}{$\begin{array}{c}\text { indirect } \\
\text { effects }\end{array}$} & \multirow{2}{*}{$\begin{array}{c}\begin{array}{c}\text { total } \\
\text { effect } \\
\mathrm{s}\end{array} \\
.960\end{array}$} & \multirow{2}{*}{$\begin{array}{l}\text { path effects } \\
\begin{array}{l}\text { creativity -> self- } \\
\text { leadership }\end{array}\end{array}$} \\
\hline \multirow{4}{*}{$\begin{array}{l}\text { exogenously } \\
\text { variables }\end{array}$} & \multirow{4}{*}{ creativity } & & & & \\
\hline & & .896 & - & .896 & $\begin{array}{l}\text { creativity -> self- } \\
\text { determination }\end{array}$ \\
\hline & & .803 & - & .803 & $\begin{array}{c}\text { creativity -> career } \\
\text { decision-making self- } \\
\text { efficacy }\end{array}$ \\
\hline & & -3.202 & 3.728 & .526 & $\begin{array}{l}\text { creativity -> career } \\
\text { preparation behavior }\end{array}$ \\
\hline \multirow{3}{*}{$\begin{array}{c}\text { endogenous } \\
\text { variables }\end{array}$} & $\begin{array}{c}\text { self- } \\
\text { leadership }\end{array}$ & 3.000 & - & 3.000 & $\begin{array}{l}\text { self-leadership -> career } \\
\text { preparation behavior }\end{array}$ \\
\hline & $\begin{array}{c}\text { self- } \\
\text { determinatio } \\
\mathrm{n}\end{array}$ & .621 & - & .621 & $\begin{array}{c}\text { self-determination -> } \\
\text { career preparation behavior }\end{array}$ \\
\hline & $\begin{array}{c}\text { career } \\
\text { decision- } \\
\text { making } \\
\text { self-efficacy }\end{array}$ & .364 & - & .364 & $\begin{array}{c}\text { career decision-making } \\
\text { self-efficacy -> career } \\
\text { preparation behavior }\end{array}$ \\
\hline
\end{tabular}

\subsection{Mediating Effects between the Measured Variables for the Measurement Model Validation}

Table 5. Mediating Effects validation result between the measured variables for measurement model

\begin{tabular}{|c|c|c|c|}
\hline \multicolumn{3}{|c|}{ variables path between } & \multirow[b]{2}{*}{$Z_{a b}$} \\
\hline $\begin{array}{l}\text { independent } \\
\text { variable }\end{array}$ & $\begin{array}{l}\text { medium } \\
\text { variable }\end{array}$ & $\begin{array}{c}\text { dependent } \\
\text { variable }\end{array}$ & \\
\hline creativity & $\begin{array}{c}\text { self-leadership } \\
\text { self-determination } \\
\text { career decision-making self- } \\
\text { efficacy }\end{array}$ & $\begin{array}{l}\text { career prepa- } \\
\text { ration behavior }\end{array}$ & $\begin{array}{l}1.959^{*} \\
1.514^{*} \\
2.242^{*}\end{array}$ \\
\hline
\end{tabular}




\section{Discussion and Conclusion}

Research results are as follows: First, creativity has a positive significant influence on career preparation behavior. Second, creativity has a positive significant influence on self-leadership, self-determination, and career decision-making self-efficacy. Third, self-leadership, self-determination, and career decision-making self-efficacy have a positive significant influence on career preparation behavior. Fourth, creativity has a significant influence on career preparation behavior with a mediation of self-leadership, self-determination, and career decision-making self-efficacy, which means creativity has an indirect influence on career preparation behavior through self-leadership, self-determination, and career decision-making self-efficacy. College education can influence career preparation behavior of college students through the creativity, self-leadership, self-determination, and career decision-making selfefficacy.

Based on the findings of this study, we have a list of suggestions for these types of programs: First, to promote activities related with the future career of college students, college students should be supported for an immersion in with conviction of their goals and in planning for the right career direction Second, developing and managing a systematic program to improve the career preparation behavior of college students should be implemented, through which their autonomy, efficacy, and relationship can be improved for career preparation behavior to be able to be applied to various fields of life and real employment. Third, applying a variety of teaching methods is necessary in order to establish an appropriate community in time for career guidance and school activities as career preparation behavior improvement is influenced by creativity, self-leadership, self-determination, and career decision-making self-efficacy.

\section{REFERENCES}

[1] Lee, S. K., Mediating Effect of Commitment to Career Choice between Self-Determination and Career Preparation Behavior of Students at Vocational Training School. The Graduate School of Education Ewha Womans National University (2015).

[2] Ryu, J. S., The Structural Relationships Among Social Support, Family Resilience, Self-determination, Commitment to Career Choice and Career Preparation Behavior of Undergraduate Students. The Graduate School Chungbuk National University(2012).

[3] Park, J. Y., A Study on the Effect of College Students' Self-Directed Learning, Creativity, Personal Relationship in regards to Career Decision Making and Career Preparation Behavior. The Graduate School Kwandong National University( 2013).

[4] [4] Lee, J. C., The Influence of University Students' Self-leadership upon Career Preparation Behavior and Mediating Effect of Career Decision Self-efficacy and Employability. The Graduate School of ChungAng National University(2013).

[5] Ryu, J. S., The Structural Relationships Among Social Support, Family Resilience, Self-determination, Commitment to Career Choice and Career Preparation Behavior of Undergraduate Students. The Graduate School Chungbuk National University(2012).

[6] Jeong, Y. L., Park, Y. H., Development and Validation of Everyday Creativity Scale. Research Institute of Education Korea University, 17(2002), 155-183. 
Myeung-sin Park, Sang-hoon Han; A Structural Analysis on the Creativity, Self-Leadership, Self-Determination, Career Decision-Making Self-Efficacy, and Career Preparation Behavior of College Students who participated in the Training Courses from Lifelong Educators, Advances in Image and Video Processing, Volume 5 No 4, Aug (2017); pp: 11-16

[7] Houghton \& Neck., The revised self-leadership questionnaire: Testing a hierarchical factor structure for self-leadership. Journal of Managerial Psychology, 17(2002), 672-691.

[8] Lee, K. H, Lee, H. J., Validation studies for efficacy as predictors of college students on career attitude maturity. Korean journal of counseling and psychology, 12(2000), 127-136.

[9] Betz, N. E., Klein, K. L., \& Taylor, K. M., Evaluation of a short from of the career decision-making selfefficacy scale. Journal of Career Assessment, 4(1996), 47-57.

[10] Ko, T. Y., The Influence of Social Support, Career Decision-Making Self-Efficacy and Career Barriers on Career Preparation Behavior of College Students. The Graduate School of Mokpo National University (2008). 